\title{
The Relationship between Pricing and Consumers Switching Costs: Comparisons between the Myopic and Perfect-foresight Equilibria
}

\author{
Omar A. Abdelrahman ${ }^{1}$ \\ ${ }^{1}$ Faculty of Administrative and Financial Sciences, Arab American University, West bank, Palestine \\ Correspondence: Omar A. Abdelrahman, Faculty of Administrative and Financial Sciences, Arab American \\ University, Jenin, West bank, Palestine. E-mail: omar.rahman@aauj.edu
}

Received: January 7, 2017

Accepted: February 9, 2017

Online Published: February 22, 2017

doi:10.5539/ibr.v10n3p221

URL: https://doi.org/10.5539/ibr.v10n3p221

\begin{abstract}
In many markets, consumers face costs of switching to a competitor's brand that is ex ante undifferentiated even when the two firms' brands are functionally identical. This study examines the relationship between pricing and consumers witching costs or "brand loyalty". Moreover, it suggests that in the presence of switching costs, firms will charge lower prices in the first period to gain market share that will be valuable to them in the future and therefore charge higher prices later utilizing the market shares they have gained in the first period. This will give firms a degree of monopoly power over their existing customers, leading to higher prices and profits in the future. This will happen if firms have perfect foresight, and it may lead to either higher or lower equilibrium profits than if firms behave myopically.
\end{abstract}

Keywords: switching costs, duopoly, myopic, perfect-foresight

\section{Introduction}

Switching costs refer to the notion of the hidden costs a consumer is faced when switching from one product to another in the market place. Switching costs are present every time an economic agent change his supplier. As such ex-ante homogeneous products become ex-post heterogeneous. The theoretical assumption about switching costs is that once a consumer purchases a product he is locked-in it. Switching costs are developed by companies in order to establish consumer's lock in (Klemperer, 1987a). Klemperer (1987a) and Nilssen (1992) argued that there are two main types of switching costs: transactions costs, learning costs.

Transaction costs are costs associated with each switch a consumer makes between identical products or services. Learning costs are costs that are associated with how to use a new product or service incurred when a consumer switch to a new supplier. While Klemperer calls the above mentioned costs "real social costs", Nilssen (1992) argues that an increase in transaction costs increases the price offered to loyal customers.

Consumer's switching costs have important strategic implications for firms that compete aggressively to gain market share before consumers attach themselves to suppliers. Switching costs may influence consumers' behaviors by increasing loyalty and making it difficult for these customers to switch, on one hand. On the other hand, reducing switching costs for potential customers may make it easier to acquire new customers. Moreover, switching costs can create a barrier to entry for new supplying firms (Klemperer, 1987a).

The purpose of this paper is to use a simple version of two-period model of Bertrand-type price competition among firms in order to show that in the presence of switching costs (or "brand loyalty"), firms will charge lower prices in the first period to gain market share and higher prices in the future utilizing the market share gained in the first period. This will happen if firms have perfect foresight, and it may lead to either higher or lower equilibrium profits than if firms behave myopically. This paper is an attempt to visit the traditional theoretical literature that studied the impact of consumer switching costs on price competition.

This study examines the relationship between pricing and consumers switching costs or brand loyalty. Moreover, it suggests that in the presence of switching costs, firms will charge lower prices in the first period to gain market share that will be valuable to them in the future and therefore charge higher prices later utilizing the market shares they have gained in the first period. 


\section{Overview of Literature}

The basic intuition of competition with switching costs was introduced by Klemperer (1987a) by employing a two-period Bertrand-type price competition model to show that firms compete aggressively in the early stages of the market development to gain market share that will be valuable to them in the second period (the mature market). Klemperer (1987b) examined a two - period differentiated product duopoly in which customers are locked in by switching costs they face in the second period which resulted in higher prices in both periods. Klemperer's (1978b) model showed that the existence of switching costs will lead to market segmentation resulting in an outcome similar to the collusive solution outcome; therefore, firms compete aggressively in the first period to attract buyers whom they can later exploit.

Klemperer (1987c) examined the influence of switching costs on existing firm's pricing behavior in the presence of high or low switching costs. Ferrell and Shapiro (1988) found that equilibrium prices tend to be higher in markets with switching costs than markets without them. They also argued that switching costs give some monopoly power to suppliers over their existing customers by charging price above competitors by an amount equal to the buyer's switching costs. Thus switching costs may weaken competition among existing firms and enhance monopoly power.

Beggs and Klemperer (1992) used an infinite -horizon model of two differentiated product firms facing existing and new customers. They found that even though prices are higher than in markets without switching costs which are large enough to prevent customers from switching among products. Padilla (1995) analyzed in an infinite-horizon model of duopolistic competition with switching costs and showed that the sustainability of collusion is more difficult to achieve in the presence of switching costs. To (1996) used an infinite horizon model of overlapping generation model in the presence of switching costs and argues that charging higher prices by firms with high locked- in customers will result in a lower market share in the future leading to lower prices. In summary, this theoretical work shows that switching costs may either raise or lower prices although the evidence leans toward less competition.

Because it is difficult in most contexts to measure switching costs, limited empirical results are available. There is a small amount of empirical research that that supports the positive correlation between pricing and switching costs. Sharp (1997) used data on bank retail deposit-interest rates and finds that switching costs have a large influence on the bank retail deposit- interest rates. Stango (2002) presented a dynamic model of price competition to explain the emphasis that credit card issuers place on building market shares. Credit card issuers charge lower rates in the first period and higher rates in the second period utilizing the market shares they have gained in the first period. Kim, Klinger and Vale (2003) used an empirical model in the banking industry in the presence of switching costs. They found that switching costs are substantial in the banking industry. They also found about one third of the average bank's market share come from bank-borrower's' relationship. Credit card issuing banks face a trade-off between offering low introductory rates in the first period (the primary market) to attract consumers and lock them in and charge high rates in the second period to extract extraordinary profits (rents) from its already locked-in customers.

More recent research on switching costs challenged Klemperer's conventional wisdom of positive correlation between equilibrium prices and switching costs. Rather than focusing on a two-period price competition model, new researchers employ an infinite-horizon model related to real-world markets in which trading does not end at some period of time. Dube, Hitsch and Rossi (2006) found that equilibrium prices are lower in markets with switching costs than without switching costs. . This is the case where credit card issuers are acting with perfect foresight. The most recent research work in switching costs was introduced by Viard, 2007.

He argued that switching costs make markets less competitive. In his empirical study, Viard found that firms have an incentive to utilize their market and charge higher prices rather than capturing more consumers to lock in. Doganoglu (2010) analyzed a dynamic duopoly with an infinite horizon and finds that in the presence of low switching costs, the prices in the steady state are lower than if these costs are absent.

In the presence of low switching costs, competition can be fiercer. Rhodes (2011) introduced a theoretical model of dynamic competition and showed that switching tended to increase prices in the short-run. However, switching costs long run effect on prices is ambiguous. Somaini and Einav (2012) found that switching costs could make markets either more or less competitive. They concluded that Markets with patient consumers and inpatient firms will produce anti-competitive effects.

Carbrel (2012) argued that switching costs make competitive markets where the sellers' discount factor is very high) even more competitive. However, if markets are not very competitive in the first place, then switching costs make them even less competitive. Pearcy (2015) showed that switching costs, and some other factors such 
as the number of firms determine whether firms offer low or high prices. He also showed that number of firms in the industry determines whether switching costs are pro- or anti-competitive. Switching costs tend to facilitate lower (higher) equilibrium prices when switching costs are small (large).

\section{The Model}

This model consisted of a single industry within a country consisting of two duopolists selling to domestic consumers. Consider two firms "A and B" producing functionally identical products. They are competing in two different markets: a first-period "primary market", and a second-period "mature market". The primary market is the first level of competition between firms to capture market share that will be valuable to them in the second period (the mature market). Because market share is valuable to these firms in the future, they compete more aggressively than they otherwise would to capture the highest market share possible. The mature market (the second market) is the second level of competition where firms compete for each other's existing customers. Firms will choose their strategic variables $\left(\mathrm{P}_{1}, \mathrm{P}_{2}\right)$ to maximize their total discounted future profits.

For example, they may choose to offer lower prices in the first period to attract consumers, on one hand. On the other hand, firms also recognize that their second-period profits depend on their first-period sales and therefore they have an incentive to invest in their market shares. Since demand is symmetric between the two banks, it is sufficient to analyze the model from the viewpoint of one of the firms. In the following, I analyze it from the viewpoint of firm A.

Firm A's first-period (primary market) and second-period (mature market) profits functions are

$$
\begin{gathered}
\pi_{1 \mathrm{~A}}\left(\mathrm{P}_{1 \mathrm{~A}}, \mathrm{P}_{1 \mathrm{~B}}\right)=\left(\mathrm{P}_{1 \mathrm{~A}}-\mathrm{C}\right) \mathrm{S}_{1 \mathrm{~A}}\left(\mathrm{P}_{1 \mathrm{~A}}, \mathrm{P}_{1 \mathrm{~B}}\right)-\mathrm{F} \\
\pi_{2 \mathrm{~A}}\left(\mathrm{P}_{2 \mathrm{~A}}, \mathrm{P}_{2 \mathrm{~B}}, \mathrm{P}_{1 \mathrm{~A}}, \mathrm{P}_{1 \mathrm{~B}}\right)=\left(\mathrm{P}_{2 \mathrm{~A}}-\mathrm{C}\right) \mathrm{S}_{2 \mathrm{~A}}\left(\mathrm{P}_{2 \mathrm{~A}}, \mathrm{P}_{2 \mathrm{~B}}, \mathrm{~S}_{1 \mathrm{~A}}\left(\mathrm{P}_{1 \mathrm{~A}}, \mathrm{P}_{1 \mathrm{~B}}\right)\right)-\mathrm{F}
\end{gathered}
$$

Where:

$\pi_{1 \mathrm{~A}}$ is firm A's first-period profits,

$\pi_{2 \mathrm{~A}}$ is firm A's second-period profits,

$\mathrm{P}_{1 \mathrm{~A}}$ is firm A's first-period price,

$\mathrm{P}_{1 \mathrm{~B}}$ is firm B's first-period price,

$\mathrm{S}_{1 \mathrm{~A}}$ is the demand function for firm A's credit cards (Market Share) in the first period,

$\mathrm{S}_{1 \mathrm{~B}}$ is the demand function for firm B's credit cards in the first period,

$\mathrm{C}$ is the (constant) marginal cost for each firm,

$\mathrm{P}_{2 \mathrm{~A}}$ is firm A's second-period price,

$\mathrm{P}_{2 B}$ is firm B's second-period price,

$\mathrm{S}_{2 \mathrm{~A}}$ is firm A's second-period demand function,

$\mathrm{S}_{2 \mathrm{~B}}$ is firm B's second-period demand function,

$F$ is fixed cost.

Firm A's total discounted profits are given by

$$
\pi_{\mathrm{A}}=\pi_{1 \mathrm{~A}}+\lambda \pi_{2 \mathrm{~A}}
$$

Where $\lambda$ is a discount factor.

The symmetric direct demand functions for the two firms in the first period given prices $\left(\mathrm{P}_{1 \mathrm{~A}}, \mathrm{P}_{1 \mathrm{~B}}\right)$ are

$$
\begin{aligned}
& \mathrm{S}_{1 \mathrm{~A}}\left(\mathrm{P}_{1 \mathrm{~A}}, \mathrm{P}_{1 \mathrm{~B}}\right)=\alpha-\beta \mathrm{P}_{1 \mathrm{~A}}+\gamma \mathrm{P}_{1 \mathrm{~B}} \\
& \mathrm{~S}_{1 \mathrm{~B}}\left(\mathrm{P}_{1 \mathrm{~A}}, \mathrm{P}_{1 \mathrm{~B}}\right)=\alpha-\beta \mathrm{P}_{1 \mathrm{~B}}+\gamma \mathrm{P}_{1 \mathrm{~A}}
\end{aligned}
$$

Where:

$\alpha, \beta$, and $\gamma$ are the parameters of the demand function. The natural restrictions are that $\alpha>0$ and $\beta \geq \gamma \geq 0$. Equation (4) states that market demand for firm A's product is downward sloping in its own price (law of demand) and increases with increases in its competitor's price (since the goods are substitutes). When $\gamma=0$, the products are independent or unrelated and each firm has monopolistic market power. Whenever $\gamma=0$, the products are substitutes. If $\gamma=\beta$,the total demand for the two goods is fixed (as seen by adding (4) and (5)). The economic meanings of the above demand functions parameters are as follows. $\alpha$ is a positive constant.

It measures quality in a vertical sense. Other things being equal, an increase in $\alpha$ increases the marginal utility of 
consuming the good. $\beta$ is the slope of the demand curve. It captures the degree of „own price sensitivity, indicating how quantity demanded is affected by a change in own price. $\gamma$ measures the substitutability between the products, indicating how quantity demanded is affected by a change in the cross-price of related goods (bank B's price).

Each firm competes by setting its price (Bertrand competition) and letting the market clear. The oligopolistic structure is one of Bertrand price setters in a differentiated product market. In period 1, firm A chooses its first-period price to maximize its total discounted future profits, taking firm B's first-period price as given.

Substituting (4) in (1), firm A's first-period profit function becomes

$$
\pi_{1 \mathrm{~A}=}\left(\mathrm{P}_{1 \mathrm{~A}}-\mathrm{C}\right)\left(\alpha-\beta \mathrm{P}_{1 \mathrm{~A}}+\gamma \mathrm{P}_{1 \mathrm{~B}}\right)-\mathrm{F}
$$

The second-period demand function faced by firm A's is assumed to be given by

$$
\begin{gathered}
\mathrm{S}_{2 \mathrm{~A}}\left(\mathrm{P}_{2 \mathrm{~A}}, \mathrm{P}_{2 \mathrm{~B}}, \mathrm{~S}_{1 \mathrm{~A}}\left(\mathrm{P}_{1 \mathrm{~A}}, \mathrm{P}_{1 \mathrm{~B}}\right)\right)=\mathrm{A}-\beta \mathrm{P}_{2 \mathrm{~A}}+\gamma \mathrm{P}_{2 \mathrm{~B}}+\delta \mathrm{S}_{1 \mathrm{~A}}\left(\mathrm{P}_{1 \mathrm{~A}}, \mathrm{P}_{1 \mathrm{~B}}\right) \\
=\mathrm{A}-\beta \mathrm{P}_{2 \mathrm{~A}}+\gamma \mathrm{P}_{2 \mathrm{~B}}+\delta\left(\alpha-\beta \mathrm{P}_{1 \mathrm{~A}}+\gamma \mathrm{P}_{1 \mathrm{~B}}\right)
\end{gathered}
$$

where the second equality follows from (4), $\mathrm{A}$ is a positive constant, and $\delta$ is a parameter that measures the extent to which consumers who previously used firm A's product in the first-period are locked into the firm's product in the second period.

Substituting (7) in (2), the second period (the mature market) profits become

$$
\pi_{2 \mathrm{~A}}=\left(\mathrm{P}_{2 \mathrm{~A}}-\mathrm{C}\right)\left(\mathrm{A}-\beta \mathrm{P}_{2 \mathrm{~A}}+\gamma \mathrm{P}_{2 \mathrm{~B}}+\delta\left(\alpha-\beta \mathrm{P}_{1 \mathrm{~A}}+\gamma \mathrm{P}_{1 \mathrm{~B}}\right)\right)-\mathrm{F}
$$

Assume first that each firm acts myopically and ignores the effect that its first-period price has on its second-period profits. Differentiating (6) with respect to $\mathrm{P}_{1 \mathrm{~A}}$, we obtain the first-period price setting equilibrium. The first order condition for firm A's profit maximizing problem is given by

$$
\frac{\partial \pi_{1 A}}{\partial P_{1 A}}=\alpha-2 \beta \mathrm{P}_{1 \mathrm{~A}}+\gamma \mathrm{P}_{1 \mathrm{~B}}+\mathrm{C} \beta=0
$$

Setting $\mathrm{p}_{1}=\mathrm{p}_{1 \mathrm{~A}}=\mathrm{p}_{1 \mathrm{~B}}$ and solving, we have the first-period symmetric equilibrium price in the myopic case

$$
P_{1}=P_{1 A}=P_{1 B}=\frac{\alpha+c \beta}{2 \beta-\gamma}
$$

Differentiating (8) with respect to $\mathrm{P}_{2 \mathrm{~A}}$, we can derive the second-period non-cooperative price setting equilibrium. The first order condition for firm A's profit maximization problem in the myopic case is given by

$$
\frac{\partial \pi_{2 A}}{\partial P_{2 A}}=\mathrm{A}-2 \beta \mathrm{P}_{2 \mathrm{~A}}+\gamma \mathrm{P}_{2 \mathrm{~B}}+\delta \alpha-\beta \mathrm{P}_{1 \mathrm{~A}} \delta+\delta \gamma \mathrm{P}_{1 \mathrm{~B}}+\mathrm{C} \beta=0
$$

Setting $\mathrm{p}_{1}=\mathrm{p}_{1 \mathrm{~A}}=\mathrm{p}_{1 \mathrm{~B}}$, and $\mathrm{p}_{2}=\mathrm{p}_{2 \mathrm{~A}}=\mathrm{p}_{2 \mathrm{~B}}$ and then solving for $\mathrm{p}_{2}$, we get the second-period symmetric equilibrium price

$$
P_{2}=P_{2 A}=P_{2 B}=\frac{A+\delta\left(\alpha-P_{1}(\beta-\gamma)\right)+C \beta}{2 \beta-\gamma}
$$

Substituting (10) in (12), we obtain the second-period symmetric equilibrium price in the myopic case

$$
P_{2}=P_{2 A}=P_{2 B}=\frac{A+\delta\left(\alpha-\left(\frac{\alpha+C \beta}{2 \beta-\gamma}\right)(\beta-\gamma)\right)+C \beta}{2 \beta-\gamma}
$$

Consider now a perfect foresight case analysis where each firm sets its first-period price, taking into account not only the effect of doing so on its first-period profitability, but also the effect on its first-period market share, and hence the second-period profitability. Firm A chooses its prices to maximize its total future discounted profit. If firms care about the future, then they will compete more fiercely for new customers since these customers will become valuable repeat-purchasers in the second period. In the two-period model of Klemperer (1987a, b) this implies charging lower prices in the first period than in the absence of this effect. In period 1, firm A chooses its first-period price $\mathrm{p}_{1 \mathrm{~A}}$ to maximize its total discounted future profits, taking firm B's first-period price as given.

Combining (6) and (8), firm A's total discounted future profits are given by 


$$
\pi_{\mathrm{A}}=\left(\mathrm{P}_{1 \mathrm{~A}}-\mathrm{C}\right)\left(\alpha-\beta \mathrm{P}_{1 \mathrm{~A}}+\gamma \mathrm{P}_{1 \mathrm{~B}}\right)-\mathrm{F}+\lambda\left[\left(\mathrm{P}_{2 \mathrm{~A}}-\mathrm{C}\right)\left(\left(\mathrm{A}-\beta \mathrm{P}_{2 \mathrm{~A}}+\gamma \mathrm{P}_{2 \mathrm{~B}}\right)+\delta\left(\alpha-\beta \mathrm{P}_{1 \mathrm{~A}}+\gamma \mathrm{P}_{1 \mathrm{~B}}\right)\right)-\mathrm{F}\right]
$$

Differentiating (14) with respect to $\mathrm{P}_{1 \mathrm{~A}}$, we get

$$
\frac{\partial \pi_{A}}{\partial P_{1 A}}=\alpha-2 \beta \mathrm{P}_{1 \mathrm{~A}}+\gamma \mathrm{P}_{1 \mathrm{~B}}+\mathrm{C} \beta-\lambda \mathrm{P}_{2 \mathrm{~A}} \delta \beta+\mathrm{C} \delta \beta \lambda=0
$$

In a symmetric equilibrium where $\mathrm{p}_{1}=\mathrm{p}_{1 \mathrm{~A}}=\mathrm{p}_{1 \mathrm{~B}}$ and $\mathrm{p}_{2}=\mathrm{p}_{2 \mathrm{~A}}=\mathrm{p}_{2 \mathrm{~B}}$

$$
P_{1}=\mathrm{P}_{1 \mathrm{~A}}=P_{1 B}=\frac{\alpha+c \beta(1+\lambda \delta)-\lambda \delta \beta P_{2}}{2 \beta-\gamma}
$$

Differentiating (14) with respect to $\mathrm{P}_{2 \mathrm{~A}}$, we get

$$
\frac{\partial \pi_{A}}{\partial P_{2 A}}=\lambda \mathrm{A}-2 \lambda \beta \mathrm{P}_{2 \mathrm{~A}}+\lambda \gamma \mathrm{P}_{2 \mathrm{~B}}+\lambda \delta \alpha-\lambda \delta \beta \mathrm{P}_{1}+\lambda \delta \gamma \mathrm{P}_{1}+\lambda \beta \mathrm{C}=0
$$

and making the same symmetry assumptions stated before (16), we get

$$
P_{2}=P_{2 A}=P_{2 B}=\frac{A+\delta \alpha-\delta \beta P_{1}+\delta \gamma P_{1}+c \beta}{2 \beta-\gamma}
$$

Rearranging (16) and (18), yields

$$
\begin{aligned}
& (2 \beta-\gamma) \mathrm{P}_{1}+(\lambda \delta \beta) \mathrm{P}_{2}=\alpha+\mathrm{C} \beta+\mathrm{C} \beta \delta \lambda \\
& (\delta \beta-\delta \gamma) \mathrm{P}_{1}+(2 \beta-\gamma) \mathrm{P}_{2}=\mathrm{A}+\delta \alpha+\mathrm{C}
\end{aligned}
$$

Using Cramer's rule, we can solve for $\mathrm{p}_{1}$ and $\mathrm{p}_{2}$ to derive the non-cooperative price-setting equilibrium in both periods in the perfect foresight case:

$$
\begin{aligned}
& P_{1}=\frac{\left|\begin{array}{cr}
\alpha+C \beta+C \beta \delta \lambda & \lambda \delta \beta \\
A+\delta \alpha+C \beta & 2 \beta-\gamma
\end{array}\right|}{\left|\begin{array}{lr}
2 \beta-\gamma & \lambda \delta \beta \\
\delta(\beta-\gamma) & 2 \beta-\gamma
\end{array}\right|} \\
& =\frac{(\alpha+C \beta+C \beta \delta \lambda)(2 \beta-\gamma)-(A+\delta \alpha+C \beta)(\lambda \delta \beta)}{(2 \beta-\gamma)(2 \beta-\gamma)-(\delta \beta-\delta \gamma)(\lambda \delta \beta)} \\
& P_{2}=\frac{\left|\begin{array}{rr}
2 \beta-\gamma & \alpha+C \beta+C \beta \delta \lambda \\
\delta \beta-\delta \gamma & A+\delta \alpha+C \beta
\end{array}\right|}{\left|\begin{array}{lr}
2 \beta-\gamma & \lambda \delta \beta \\
\delta(\beta-\gamma) & 2 \beta-\gamma
\end{array}\right|} \\
& =\frac{(2 \beta-\gamma)(A+\delta \alpha+C \beta)-(\delta \beta-\delta \gamma)(\alpha+C \beta+C \beta \delta \lambda)}{(2 \beta-\gamma)(2 \beta-\gamma)-(\delta \beta-\delta \gamma)(\lambda \delta \beta)}
\end{aligned}
$$

\section{Comparisons between the Myopic and Perfect-Foresight Equilibria}

3.1 The Case $C=0$ and $\delta=0$

From (10) and (13) with $\boldsymbol{\delta}=0$, it follows that the equilibrium prices in the first and second periods in the myopic case are

$$
\begin{aligned}
& P_{1}=P_{1 A}=P_{1 B}=\frac{\alpha+C \beta}{2 \beta-\gamma} \\
& P_{2}=P_{2 A}=P_{2 A}=\frac{A+C \beta}{2 \beta-\gamma}
\end{aligned}
$$

Similarly, from (21) and (22) with $\boldsymbol{\delta}=0$, it follows that the equilibrium prices in the first and second periods in the perfect foresight case are

$$
\begin{gathered}
P_{1}=P_{1 A}=P_{1 B}=\frac{\alpha+C \beta}{2 \beta-\gamma} \\
P_{2}=P_{2 A}=P_{2 A}=\frac{A+C \beta}{2 \beta-\gamma}
\end{gathered}
$$

I will consider the following parameter values for numerical example 1 


$$
\alpha=10, \mathrm{~A}=10, \lambda=0.7, \beta=2, \delta=0, \gamma=1, \mathrm{C}=0, \mathrm{~F}=0 .
$$

Inserting $\mathrm{C}=0$ and the values in (27) in equations (23) and (34), the Myopic prices are

$$
\begin{aligned}
& P_{1}=P_{1 A}=P_{1 B}=\frac{\alpha}{2 \beta-\gamma}=3.333 \\
& P_{2}=P_{2 A}=P_{2 B}=\frac{A}{2 \beta-\gamma}=3.333
\end{aligned}
$$

Inserting $\mathrm{C}=0$ and the values in (27) in equations (25) and (26), the perfect-foresight prices are

$$
\begin{aligned}
& P_{1}=P_{1 A}=P_{1 B} \quad=\frac{\alpha}{2 \beta-\gamma}=3.333 \\
& P_{2}=P_{2 A}=P_{2 B}=\frac{A}{2 \beta-\gamma}=3.333
\end{aligned}
$$

We have, from (23)-(26), or from (28)-(31),

Proposition 1: In the case, $\boldsymbol{\delta}=0$, so there are no switching costs (or "brand loyalty") in the second period, then the first-period equilibrium price in the myopic case is equal to the first-period equilibrium price in the perfect foresight case, and the second-period equilibrium price in the myopic case is equal to the second-period equilibrium in the perfect foresight case.

Using equations (6), (8), $\mathrm{P}_{1}=\mathrm{P}_{1 \mathrm{~A}}=\mathrm{P}_{1 \mathrm{~B}}, \mathrm{P}_{2}=\mathrm{P}_{2 \mathrm{~A}}=\mathrm{P}_{2 \mathrm{~B}}$ and (27), the equilibrium profits of each firm in the first and second periods are

$$
\begin{aligned}
& \pi_{1}=\pi_{1 \mathrm{~A}}=\pi 1 \mathrm{~B}=\mathrm{P}_{1}\left(\alpha-\beta \mathrm{P}_{1}+\gamma \mathrm{P}_{1}\right) \\
& \pi_{2}=\pi_{2 \mathrm{~A}} \pi 2 \mathrm{~B}=\mathrm{P}_{2}\left(\mathrm{~A}-\beta \mathrm{P}_{2}+\gamma \mathrm{P}_{2}\right)
\end{aligned}
$$

From (3), (32) and (33), each firm's present value of profits is

$$
\pi_{\mathrm{A}}=\pi_{\mathrm{B}}=\pi_{1}+\lambda \pi_{2}
$$

First consider profits in the myopic case. Using equations (27), (28), and (32), profits in the first period are

$$
\pi_{1}=\pi_{1 \mathrm{~A}}=\pi_{1 \mathrm{~B}}=\mathrm{P}_{1}\left(\alpha-\beta \mathrm{P}_{1}+\gamma \mathrm{P}_{1}\right)=\frac{\alpha^{2} \beta}{(2 \beta-\gamma)^{2}}=22.221
$$

Using equations (27), (29), and (33), profits in the second period are

$$
\pi_{2 \mathrm{~A}}=\pi_{2 \mathrm{~A}}=\pi_{2 \mathrm{~B}}==\mathrm{P}_{2}\left(\mathrm{~A}-\beta \mathrm{P}_{2}+\gamma \mathrm{P}_{2}\right)=\frac{A \beta^{2}}{(2 \beta-\gamma)^{2}}=22.221
$$

Using equations (27), (34), (35) and (36), it follows that the total discounted future profits are:

$$
\pi_{\mathrm{A}}=22.222+.7(22.221)=37.775
$$

Now consider the perfect-foresight case.

Using (27), (30), and (32), profits in the first period are

$$
\pi_{1}=\pi_{1 \mathrm{~A}}=\pi_{1 \mathrm{~B}}=\mathrm{P}_{1}\left(\alpha-\beta \mathrm{P}_{1}+\gamma \mathrm{P}_{1}\right)=\frac{\alpha^{2} \beta}{(2 \beta-\gamma)^{2}}=22.221
$$

Using equations (27), (31), and (33), profits in the second period are

$$
\pi_{2 \mathrm{~A}}=\pi_{2 \mathrm{~A}}=\pi_{2 \mathrm{~B}}=\mathrm{P}_{2}\left(\mathrm{~A}-\beta \mathrm{P}_{2}+\gamma \mathrm{P}_{2}\right)=\frac{A \beta^{2}}{(2 \beta-\gamma)^{2}}=22.221
$$

From (27), (34),(38) and (39), A's total discounted profits are

We therefore have:

$$
\pi_{\mathrm{A}}=\pi_{1 \mathrm{~A}}+\lambda \pi_{2 \mathrm{~A}}=22.221+.7(22.221)=37.775
$$

Proposition 2: It can be seen that when $\boldsymbol{\delta}=0$, so there are no switching costs (or "brand loyalty") in the second market, then the profits of each firm (first period, second period, and total) are the same under myopic behavior as under perfect foresight. 
3.2 The Case $C=0$ and $\delta>0$

From (10) and (13) with $\mathrm{C}=0$, it follows that equilibrium prices in both periods in the Myopic case are

$$
\begin{gathered}
P_{1}=P_{1 A}=P_{1 B}=\frac{\alpha}{2 \beta-\gamma} \\
P_{2}=P_{2 A}=P_{2 B}=\frac{A+\delta\left(\alpha-\left(\frac{\alpha}{2 \beta-\gamma}\right)(\beta-\gamma)\right)}{2 \beta-\gamma}
\end{gathered}
$$

Using (21) and (22) with $\mathrm{C}=0$, it follows that equilibrium prices in both periods in the perfect- foresight case are

$$
\begin{gathered}
P_{1}=P_{1 A}=P_{1 B}=\frac{\alpha(2 \beta-\gamma)-\lambda \delta \beta(A+\delta \alpha)}{(2 \beta-\gamma)(2 \beta-\gamma)-(\delta \beta-\delta \gamma)(\lambda \delta \beta)} \\
P_{2}=P_{2 A}=P_{2 B}=\frac{(2 \beta-\gamma)(A+\delta)-\alpha \delta(\beta-\gamma)}{(2 \beta-\gamma)(2 \beta-\gamma)-(\delta \beta-\delta \gamma)(\lambda \delta \beta)}
\end{gathered}
$$

I will consider the following parameter values for numerical example 2

$$
\alpha=10, \mathrm{~A}=10, \lambda=0.7, \beta=2, \delta=0.2, \gamma=1, \mathrm{C}=0, \mathrm{~F}=0 .
$$

Inserting the values in (45) in equations (41) and (42), prices in the myopic case are

$$
\begin{gathered}
P_{1}=P_{1 A}=P_{1 B}=\frac{\alpha}{2 \beta-\gamma}=3.333 \\
P_{2}=P_{2 A}=P_{2 B}=\frac{\left.A+\delta\left(\alpha-\frac{\alpha}{2 \beta-\gamma}\right)(\beta-\gamma)\right)}{2 \beta-\gamma}=3.77
\end{gathered}
$$

Inserting the values in (45) in equations (43) and (44), prices under perfect foresight are

$$
\begin{gathered}
P_{1}=P_{1 A}=P_{1 B}=\frac{\alpha(2 \beta-\gamma)-(A+\delta \alpha)(\lambda \delta \beta)}{(2 \beta-\gamma)(2 \beta-\gamma)-(\delta \beta-\delta \gamma)(\lambda \delta \beta)}=2.978 \\
P_{2}=P_{2 A}=P_{2 B}=\frac{(2 \beta-\gamma)(A+\delta)-\alpha \delta(\beta-\gamma)}{(2 \beta-\gamma)(2 \beta-\gamma)-(\delta \beta-\delta \gamma)(\lambda \delta \beta)}=3.197
\end{gathered}
$$

Hence, we have:

Proposition 3: From (46)-(49), it follows that in the presence of switching costs (or "brand loyalty"), since $\delta>$ 0 , then firms will charge lower prices in the first period than if there were no switching costs, that is . $\delta=0$.

Firms acting myopically set an equilibrium price in the first period regardless of how big $\delta$ is. Firms typically sets lower prices in the first period in order to capture the market share that will be valuable to them in the future and charge higher prices in the second period. A first-period price cut that increases a firm's first-period market share (demand) foretells a second-period price rise.

Using equations (6), (8), $\mathrm{P}_{1}=\mathrm{P}_{1 \mathrm{~A}}=\mathrm{P}_{1 \mathrm{~B}}, \mathrm{P}_{2}=\mathrm{P}_{2 \mathrm{~A}}=\mathrm{P}_{2 \mathrm{~B}}$ and (45), the equilibrium profits for each firm in the first and second periods are

$$
\begin{gathered}
\pi_{1}=\pi_{1 \mathrm{~A}}=\pi_{1 \mathrm{~B}}=\mathrm{P}_{1 \mathrm{~A}}\left(\alpha-\beta \mathrm{P}_{1 \mathrm{~A}}+\gamma \mathrm{P}_{1 \mathrm{~B}}\right) \\
\pi_{2}=\pi_{2 \mathrm{~B}}=\pi_{2 \mathrm{~A}}=\mathrm{P}_{2 \mathrm{~A}}\left(\mathrm{~A}-\beta \mathrm{P}_{2 \mathrm{~A}}+\gamma \mathrm{P}_{2 \mathrm{~B}}\right)
\end{gathered}
$$

From (3), (50) and (51), each firm present profits are:

$$
\pi_{\mathrm{A}}=\pi_{\mathrm{B}}=\pi_{1}+\lambda \pi_{2}
$$

First consider profits in the myopic case. Using equations (45), (46), and (50), profits in the first period are

$$
\pi_{1 \mathrm{~A}}=\pi_{1 \mathrm{~A}}=\pi_{1 \mathrm{~B}}=\mathrm{P}_{1 \mathrm{~A}}\left(\alpha-\beta \mathrm{P}_{1 \mathrm{~A}}+\gamma \mathrm{P}_{1 \mathrm{~B}}\right)=22.222
$$

Using equations (45), (47), and (51), profits in the first period are

$$
\pi_{1}=\pi_{1 \mathrm{~A}}=\pi_{1 \mathrm{~B}}==\mathrm{P}_{2 \mathrm{~A}}\left(\mathrm{~A}-\beta \mathrm{P}_{2 \mathrm{~A}}+\gamma \mathrm{P}_{2 \mathrm{~B}}\right)=28.542
$$

Using equations (45), (52), (53) and (54), it follows that total discounted future profits are under myopic case are:

$$
\pi_{\mathrm{A}}=22.222+.7(28.544)=42.200
$$


Now consider the Perfect foresight Case. Using (45), (48), and (50), profits in the first period are

$$
\pi_{1}=\pi_{1 \mathrm{~A}}=\pi_{1 \mathrm{~B}}=\mathrm{P}_{1 \mathrm{~A}}\left(\alpha-\beta \mathrm{P}_{1 \mathrm{~A}}+\gamma \mathrm{P}_{1 \mathrm{~B}}\right)=20.913
$$

Using (45), (48), and (51), profits in the second period are

$$
\pi_{2}=\pi_{2 \mathrm{~A}}=\pi_{2 \mathrm{~B}}=\mathrm{P}_{2 \mathrm{~A}}\left(\mathrm{~A}-\beta \mathrm{P}_{2 \mathrm{~A}}+\gamma \mathrm{P}_{2 \mathrm{~B}}\right)=26.239
$$

From (45), (52),(56) and (57), each firm's present value of profits under perfect foresight are

We therefore have:

$$
\pi_{\mathrm{A}}=\pi_{1 \mathrm{~A}}+\lambda \pi_{2 \mathrm{~A}}=20.913+.7(26.239)=39.7278
$$

Proposition 4: From (53) through (58), we see that firm A's total discounted profits in the perfect foresight case is less than the total discounted profits in the myopic case.

In the myopic case, firm A makes more profits in both periods than it makes in the perfect foresight case. Therefore, in the presence of switching costs, firms will have a degree of monopoly power over their customers, leading to higher prices and profits in the future.

\subsection{The Case $y=0$}

From (10) and (13) with $\gamma=0$, it follows that prices in the first and second periods in the myopic case are

$$
\begin{gathered}
P_{1}=P_{1 A}=P_{1 B}=\frac{\alpha+C \beta}{2 \beta} \\
P_{2}=P_{2 A}=P_{2 B}=\frac{A+\frac{\delta \alpha}{2}+C \beta\left(1-\frac{\delta}{2}\right)}{2 \beta}
\end{gathered}
$$

Using (21) and (22) with $\gamma=0$, we obtain prices in the first and second in the perfect-foresight case are

$$
\begin{gathered}
P_{1}=P_{1 A}=P_{1 B}=\frac{2 \alpha+2 C \beta+\lambda \delta C \beta-A \lambda \delta-\lambda \delta^{2} \alpha}{4 \beta-\lambda \delta^{2} \beta} \\
P_{2}=P_{2 A}=P_{2 B}=\frac{2 A+\alpha \delta+2 C \beta-C \beta \delta-C \beta \delta^{2} \lambda}{4 \beta-\lambda \delta^{2} \beta}
\end{gathered}
$$

I will consider the following parameter values for numerical example 3

$\alpha=10, \mathrm{~A}=10, \lambda=0.7, \delta=0.2, \beta=2, \gamma=0, \mathrm{C}=0, \mathrm{~F}=0$. Inserting the values in (63) in equations (59) and (60), prices in the myopic case are

$$
\begin{gathered}
P_{1}=P_{1 A}=P_{1 B}=\frac{\alpha}{2 \beta}=2.500 \\
P_{2}=P_{2 A}=P_{2 B}=\frac{A+\frac{\delta \alpha}{2}}{2 \beta}=2.750
\end{gathered}
$$

Inserting $\mathrm{C}=0$ and other values in (63) in (61) and (62), prices in the perfect - foresight case in the first and second periods

$$
\begin{gathered}
P_{1}=P_{1 A}=P_{1 B}=\frac{2 \alpha-A \lambda \delta-\lambda \delta^{2} \alpha}{4 \beta-\lambda \delta^{2} \beta}=2.306 \\
P_{2}=P_{2 A}=P_{2 B}=\frac{2 A+\alpha \delta}{4 \beta-\lambda \delta^{2} \beta}=2.769
\end{gathered}
$$

Hence, we have:

Proposition 5: Equations (64) through (67), state equilibrium prices under the assumption of no substitutability that is $\gamma=0$ (a zero coefficient on the rival's price), then demands are unrelated or independent. This implies that demand for firm A's product does not depend at all on firm $B$ 's product price. Therefore, each firm is a monopoly in its market.

Using equations (6), (8), $\mathrm{P}_{1}=\mathrm{P}_{1 \mathrm{~A}}=\mathrm{P}_{1 \mathrm{~B}}, \mathrm{P}_{2}=\mathrm{P}_{2 \mathrm{~A}}=\mathrm{P}_{2 \mathrm{~B}}$ and (63), the equilibrium profits for each firm in the first and second periods are:

$$
\begin{array}{r}
\pi_{1}=\pi_{1 \mathrm{~A}}=\pi_{1 \mathrm{~B}}={ }_{=} \mathrm{P}_{1}\left(\alpha-\beta \mathrm{P}_{1}\right) \\
\pi_{2}=\pi_{2 \mathrm{~A}}=\pi_{2 \mathrm{~B}}==\mathrm{P}_{2}\left(\mathrm{~A}-\alpha \mathrm{P}_{2}+\delta\left(\alpha-\beta \mathrm{P}_{1}\right)\right)
\end{array}
$$


From equation (3), each firm present value of profits are:

$$
\pi_{\mathrm{A}}=\pi_{\mathrm{B}}=\pi_{1}+\lambda \pi_{2}
$$

Using equations (63), (64), (68), profits in the myopic case in the first period are

$$
\pi_{1 \mathrm{~A}}=\pi_{1 \mathrm{~A}}=\pi_{1 \mathrm{~B}}=\mathrm{P}_{1 \mathrm{~A}}\left(\alpha-\beta \mathrm{P}_{1 \mathrm{~A}}\right)=\frac{\alpha^{2}}{4 \beta}=12.500
$$

Using equations (63), (65), (69), profits in the myopic case the second period are

$$
\pi_{2 \mathrm{~A}}=\mathrm{P}_{2 \mathrm{~A}}\left(\mathrm{~A}-\beta \mathrm{P}_{2 \mathrm{~A}}+\delta\left(\alpha-\beta \mathrm{P}_{1 \mathrm{~A}}\right)\right)=\frac{A^{2}+\delta \alpha A+\frac{1}{4} \delta^{2} \alpha^{2}}{4 \beta}=15.125
$$

Using equations (63), (70), (71) and (72), the total discounted profits in the myopic case are

$$
\pi_{\mathrm{A}}=\pi_{\mathrm{B}}=12.500+0.7(15.125)=23.088
$$

Using (63), (66), and (68), profits in the perfect-foresight case are in the first period are

$$
\pi_{1 \mathrm{~A}}=\pi_{1 \mathrm{~B}}=12.425
$$

Using (63), (66), (67) and (69), profits in the perfect-foresight case are in the second period are

$$
\pi_{2}=\pi_{2 \mathrm{~A}}=\pi_{2 \mathrm{~B}}=15.339
$$

Using equation (63), (70), (74) and (75), the perfect-foresight total discounted profits are

$$
\pi_{\mathrm{A}}=\pi_{1 \mathrm{~A}}+\lambda \pi_{2}=12.425+0.7(15.339)=23.162
$$

Hence we have the following proposition:

Proposition 6: If firms ignore each other's pricing behavior, in this case $\gamma=0$, we will have lower prices and profits in both periods in both the myopic case and the perfect foresight case than if goods were substitutes or related, that is $\gamma>0$.

In addition the result tells that both firms' equilibrium profits are lower when goods are independent and products are totally differentiated in both the primary market and the mature market. In addition, firm A makes more first-period profits in the myopic case than it does in the perfect foresight case. On the other hand, firm A's second period and total discounted future profits are higher in the perfect foresight case than they are in the myopic case.

3.4 The Case where $\beta=\gamma$ and $C=0$

From (10) and (13) with $\beta=\gamma$, and $C=0$, it follows that prices in the myopic case in the first and second periods are

$$
\begin{gathered}
P_{1}=P_{1 A}=P_{1 B}=\frac{\alpha}{\beta} \\
P_{2}=P_{2 A}=P_{2 B}=\frac{A+\alpha \delta}{\beta}
\end{gathered}
$$

From (21) and (22) with $\beta=\gamma$, and $\mathrm{C}=0$, it follows that prices in the first and second periods under perfect foresight are

$$
\begin{gathered}
P_{1}=P_{1 A}=P_{1 B}=\frac{\alpha-\lambda \alpha \delta^{2}-A \lambda \delta}{\beta} \\
P_{2}=P_{2 A}=P_{2 B}=\frac{A+\alpha \delta}{\beta}
\end{gathered}
$$

I will consider the following parameter values for numerical example 4

$$
\alpha=10, \mathrm{~A}=10, \lambda=0.7, \delta=0.2, \beta=2, \gamma=2, \mathrm{C}=0, \mathrm{~F}=0 .
$$

Inserting the values in (81) in equations (77) and (78), the myopic prices in the first and second periods are

$$
\begin{aligned}
& P_{1}=P_{1 A}=P_{1 B}=\frac{\alpha}{\beta}=5.000 \\
& P_{2}=P_{2 A}=P_{2 B}=\frac{A+\alpha \delta}{\beta}=6.000
\end{aligned}
$$


Inserting the values in (81) in equations (79) and (80), prices in the first and second periods are

$$
\begin{gathered}
P_{1}=P_{1 A}=P_{1 B}=\frac{\alpha-\lambda \alpha \delta^{2}-A \lambda \delta}{\beta}=4.160 \\
P_{2}=P_{2 A}=P_{2 B}=\frac{A+\alpha \delta}{\beta}=6.000
\end{gathered}
$$

Therefore, we have the following proposition

Proposition 7: Given that the total demand for the goods is fixed, that is $\beta=\gamma$, then we will have higher prices in both periods in both the perfect foresight and the myopic cases than in the case if the total demand for the goods is independent, that is $\boldsymbol{\gamma}=\mathbf{0}$.

Consider profits. Using equations (6), (8), and (81), $\mathrm{P}_{1}=\mathrm{P}_{1 \mathrm{~A}}=\mathrm{P}_{1 \mathrm{~B}}, \mathrm{P}_{2}=\mathrm{P}_{2 \mathrm{~A}}=\mathrm{P}_{2 \mathrm{~B}}$ and $\beta=\gamma$, profits in the first period are

$$
\pi_{1 \mathrm{~A}}=\pi_{1 \mathrm{~A}}=\pi_{1 \mathrm{~B}}=\mathrm{P}_{1 \mathrm{~A}} \quad\left(\alpha-\beta \mathrm{P}_{1 \mathrm{~A}}+\gamma \mathrm{P}_{1 \mathrm{~B}}\right)=\mathrm{P}_{1} \alpha
$$

Using equations (6), (8), (81), $\mathrm{P}_{1}=\mathrm{P}_{1 \mathrm{~A}}=\mathrm{P}_{1 \mathrm{~B}}, \quad \mathrm{P}_{2}=\mathrm{P}_{2 \mathrm{~A}}=\mathrm{P}_{2 \mathrm{~B}}$ and $\beta=\gamma$, profits in the second period are

$$
\pi_{2 \mathrm{~A}}=\mathrm{P}_{2 \mathrm{~A}}\left(\mathrm{~A}-\beta \mathrm{P}_{2 \mathrm{~A}}+\delta\left(\mathrm{A}-\beta \mathrm{P}_{2 \mathrm{~A}}+\gamma \mathrm{P}_{2 \mathrm{~B}}\right)=\mathrm{P}_{2}(\mathrm{~A}+\boldsymbol{\delta} \alpha)\right.
$$

Using equations (3), the total discounted profits are

$$
\pi_{\mathrm{A}}=\pi_{\mathrm{B}=} \pi_{1 \mathrm{~A}}+\lambda \pi_{2}
$$

Using (77),(81), and (86), profits in the myopic case in the first period are

$$
\pi_{1 \mathrm{~A}}=\pi_{1 \mathrm{~B}}=50.000
$$

Using (78), (81), and (87), profits in the myopic case in the second period are

$$
\pi_{2 \mathrm{~A}}=\pi_{2 \mathrm{~B}}=72.000
$$

Using (81), (88), (89), and (90), each firm's total discounted profits in the myopic case are

$$
\pi_{\mathrm{A}}=\pi_{\mathrm{B}}=50.000+0.7(72.000)=100.400
$$

Now consider the perfect-foresight case. Using (81), (84), and (86), profits in the perfect-foresight case in the first period are

$$
\pi_{1 \mathrm{~A}}=\pi_{1 \mathrm{~B}}=41.600
$$

Using (81),(85), and (87), perfect foresight profits in the second period are

$$
\pi_{2 \mathrm{~A}}=\pi_{2 \mathrm{~B}}=72.000
$$

Using (81), (88), (92), and (93), it follows that each firm's total discounted profits in the perfect-foresight case are

$$
\pi_{1 \mathrm{~A}}=41.000+0.7(72.000)=91.400
$$

Proposition 8: The total demand for the two goods is fixed, that is $\beta=\gamma$. The first period and total discounted profits are higher in the myopic case than they are in the perfect foresight case. However, the second-period profits are the same in both the myopic case and the perfect foresight case.

\section{Conclusion}

This study showed that there is a relationship between pricing and consumers switching costs (or "brand loyalty"). Moreover, it suggested that in the presence of switching costs, firms will charge lower prices in the first period to gain market share that will be valuable to them in the future. Therefore, they charge higher prices in the future utilizing the market share they have gained in the first period. It has been shown that when $\delta=0$, so there are no switching costs (or "brand loyalty") in the second period, then the first-period equilibrium price in the myopic case is equal to the first-period equilibrium price in the perfect foresight case, and the second-period equilibrium price in the myopic case is equal to the second-period equilibrium price in the perfect foresight case.

However, in the presence of switching costs (or "brand loyalty"), that is $\delta>0$, then firms will charge lower prices in the first period than if there were no switching costs. Firms acting myopically set an equilibrium price in the first period regardless of how big $\delta$ is. Firms typically sets lower prices in the first period in order to capture the market share that will be valuable to them in the future and charge higher prices in the second period.

A first-period price cut that increases a firm's first-period market share (demand) foretells a second-period price rise. The author claims that firm's "A" total discounted profits in the perfect foresight case is less than the total discounted profits in the myopic case. In the myopic case, firm A makes more profits in both periods than it 
makes in the perfect foresight case. Therefore, in the presence of switching costs, firms will have a degree of monopoly power over their customers, leading to higher prices and profits in the future.

This will give firms a degree of monopoly power over their existing customers, leading to higher prices and profits in the future. This is also the case under the assumption of no substitutability that is $\gamma=0$ (a zero coefficient on the rival's price), when demands are unrelated or independent. This will happen if firms have perfect foresight, and it may lead to either higher or lower equilibrium profits than if firms behave myopically.

\section{References}

Beggs, A., \& Klemperer, P. (1992). Multi-Period Competition With Switching Costs. Econometrica, 60, 651-666. https://doi.org/10.2307/2951587

Cabral, L. (2012). Switching Costs and Equilibrium Prices. Working Paper, New York University.

Doganoglu, T. (2010). Switching Costs, Experience Goods and Dynamic Price Competition. Quantitative Marketing and Economics, 8(2), 167-205. https://doi.org/10.1007/s11129-010-9083-y

Dube, J. P., Hitsch, G. H., \&Rossi, P. E. (2006). Do Switching Costs make Markets Less Competitive. Journal of Marketing Research, 46(4), 435-445. http//dx.doi:10.1059/jmkr.45.4.435

Farrell, J., \& Shapiro, C. (1988). Dynamic competition with switching costs. Rand Journal of Economics, 19, 123-137. https://doi.org/10.2307/2555402

Kim, M., Klinger, D., \& Vale, B. (2003). Estimating Switching Costs: The Case of Banking. Journal of Financial Intermediation, 12, 25-56. http//dx.doi:10.1016/S1042-9573(02)00005-0

Klemperer, P. (1987a). Markets with Consumer Switching Costs. Quarterly Journal of Economics, 102, 375-394. https://doi.org/10.2307/1885068

Klemperer, P. (1987b). The competitiveness of Markets with Consumer Switching Costs. Rand Journal of economics, 18, 137-150. https://doi.org/10.2307/2555540

Klemperer, P. (1987c). Entry Deterrence in Markets with Consumer Switching Costs. Economic Journal, Supplement, 97, 99-117. https://doi.org/10.2307/3038233

Nilssen, T. (1992). Two Kinds of Consumer Switching Costs. RAND Journal of Economics, 23, 579-589. https://doi.org/10.2307/2555907

Padilla, A. J. (1995). Revisiting Dynamic Duopoly with Consumer Switching Costs. Journal of Economic Theory, 67, 520-530. https://doi.org/10.1006/jeth.1995.1083

Pearcy, J. (2015). Bargains Followed by Bargains: When Switching Costs Make Markets More Competitive. Journal of Economics and Management Strategy, 25(4), 826-851. https://doi.org/10.1111/jems.12158

Rhodes, A. (2011). Re-examining the Effects of switching costs. Oxford University.

Sharpe, S. A. (1997). The Effect of Consumer Switching Costs on Prices: A Theory and Its Application to the Bank Deposit Market. Review of Industrial Organization, 12, 79-94. https://doi.org/10.1023/A:1007748623012

Somaini, P., \& Einav, L. (2012). A Model of Market Power in Customer Markets. Stanford University.

Stango, V. (2002). Pricing With Consumer Switching Costs: Evidence from the Credit Card Market. The Journal of Industrial Economics, 50, 475-492. https://doi.org/10.1111/1467-6451.00187

To, T. (1996). Multi-Period Competition with Switching Costs: An Overlapping Generations Formulation. The Journal of Industrial Economics, 44, 81-87. https://doi.org/10.2307/2950562

Viard, V. B. (2007). Do Switching Costs Make Markets More or Less Competitive? The Case of 800-Number Portability. The RAND Journal of Economics, 38, 146-163.

https://doi.org/10.1111/j.1756-2171.2007.tb00049.x

\section{Copyrights}

Copyright for this article is retained by the author(s), with first publication rights granted to the journal.

This is an open-access article distributed under the terms and conditions of the Creative Commons Attribution license (http://creativecommons.org/licenses/by/4.0/). 